\title{
International recruitment highlights need to track scientific behaviour
}

San Diego. The increasingly tough stand being taken by US institutions against those committing misconduct in research is creating a new group of scientific fugitives researchers who seek posts in laboratories abroad after investigations by American institutions cast a cloud over their careers.

Thus a number of scientists alleged to have fabricated research data, to have falsified their academic credentials, or suspected of sabotaging experiments of their colleagues, have moved to research posts in Europe, after inquiries into their activities in the United States.

But this phenomenon has raised questions about how research institutions can obtain clear information about the history of researchers they intend to appoint, particularly if such researchers move to countries that lack a well-defined system for dealing with allegations of misconduct.

"This is a serious problem around the world," says Martin Raff, professor of biology at University College London, adding that there tends to be a lack of communication between institutions on fraud problems. "These cases keep occurring, but there seems to be no good way of dealing with them. The problem is a fear of litigation. Something needs to be done."

Stephen P. Lock, a former editor of the British Medical Journal and now a research fellow at the Wellcome Institute for the History of Medicine in London, describes the situation as a "a storm signal".

In the era of faxes and electronic mail, Lock points out, there is no excuse for not checking a scientist's credentials. But, in the face of a growing number of civil lawsuits in individual countries, international monitoring faces considerable challenges.

A typical case involves Kimon J. Angelides, a 44-year-old neurobiologist, who moved to the University of Durham in Britain last year, after losing his post at Baylor College of Medicine in Houston, Texas, for allegedly fabricating research data. Last August, Angelides filed lawsuits in state and federal courts in Houston against Baylor and the key officials in the university's investigation. Angelides is suing for defamation, blacklisting, wrongful termination and breach of contract, claiming that he had brought more than $\$ 7$ million in research grants to Baylor.

In his lawsuit, Angelides states that Baylor terminated his contract in March 1995 after the university's investigating committee had found that he had falsified or fabricated data in five scientific articles and in grant applications to the US National Institutes of Health (NIH). After the verdict, Angelides, who had been at Baylor since 1986 and was a tenured professor in the departments of cell biology and biochemistry, was escorted from his laboratory by university security guards.

Baylor subsequently notified the NIH of the findings of its investigation, prompting the agency's Office of Research Integrity (ORI) to open an inquiry. ORI officials decline to comment, as the agency has not reached a conclusion on the case. Sam Crocker, Baylor's counsel, also declines to comment, as does Angelides, who is now a professor of cell biology in the department of biological sciences at Durham.

James V. Pianelli, Angelides' attorney, describes Baylor's procedures as flawed. "There was denial of due process," he says. "Allegations were made by folks with axes to grind." A trial date of February 1997 has been set for Angelides' civil lawsuit against Baylor. ORI has put its investigation in abeyance until after the trial, says Pianelli.

Asked what Durham knew about the allegations against Angelides, Evelyn A.V. Ebsworth, the university's vice-chancellor, said: "I am not aware of the details of the problems. I have discussed some difficulties at Baylor."

Earlier in his career, Angelides fell foul of officials at McGill University in Montreal, Canada. In 1980, officials say, he was found to have listed false academic credentials in a curriculum vitae, which also included misleading citations for research articles that were not published.

Rose M. Johnstone, then chairwoman of McGill's biochemistry department, says she discovered by "a fluke" that Angelides had padded his $\mathrm{CV}$ with four or five unpublished articles and falsely listed an undergraduate degree from Harvard University. Angelides received his undergraduate degree from Lawrence University in Wisconsin. His doctorate in chemistry came from the University of California at Santa Cruz.

Johnstone says that she requested Angelides to resign, adding that she never wrote him a letter of recommendation. "He said I was making a terrible mistake because he would have brought notoriety to the department," Johnstone says. "I said that was one thing we didn't need."

Pianelli denies that Angelides misrepresented his credentials or research at McGill. Angelides left Canada for the University of Florida's College of Medicine in Gainesville, where officials say he was never investigated or found to have engaged in impropriety. But there were questions about his research.

"He was someone who could dazzle you with an enormous amount of research,"

\section{Rotation experiment returns to Cologne}

Munich. A famous experiment to prove that the Earth spins on its axis, originally conducted in 1852, was recently repeated in the southern transept of Cologne Cathedral, Germany's largest cathedral (right), to celebrate the 200th anniversary of the birth of the physicist Caspar Garthe.

Garthe suspended a lead-filled brass bowl on a steel wire from the cathedral's 45-metre-high chancel, and used two wedge-shaped scales placed just above the floor to measure its deviation from its plane of swing, a proof of the Earth's rotation.

The admission fee of 20 silver groschen, paid by 1,000 visitors during one month of daily performances, was used to help construct the Gothic cathedral. In 1851, a year before Garthe, the French physicist Léon Foucault more famously repeated the experiment in the Panthéon in Paris. $\square$

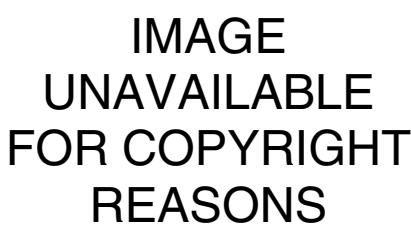


- says a prominent Florida scientist. "But senior faculty raised eyebrows that his work was not well replicated," he says.

The separate case of Timothy $\mathbf{J}$. Baldwin shows the difficulty of uncovering problems that may follow researchers moving internationally between scientific institutions. After receiving his doctorate in biology in 1985 from University College London, Baldwin went to the Massachusetts Institute of Technology (MIT) as a postdoctoral fellow in the NIH-funded laboratory of Steven J. Burden, a neuroscientist.

Whilst at MIT, those working in Burden's laboratory, including Baldwin, were investigated following sabotage to experiments, but no-one was found responsible. Baldwin left in August 1989 for a postdoctoral position at the University of California in San Francisco (UCSF). About two months after he left Massachusetts, MIT records say, Baldwin was asked to return because some molecular biology experiments he had conducted for an article published with Burden (see Nature 341, 716; 1989) could not be reproduced.

Baldwin went back to MIT, attempted unsuccessfully to repeat the experiments one day and then admitted himself to a mental hospital, MIT records say. After leaving hospital, Baldwin returned to research at UCSF, where officials were unaware of what had unfolded in Boston.

These events prompted Burden to retract a major part of the published study (see Nature 345, 364; 1990) and caused MIT to initiate an investigation into possible misconduct. This probe became a contentious affair between Baldwin and Burden. MIT decided in 1992 that it could not conclusively establish whether Baldwin had falsified the research results, largely as his laboratory notebooks had disappeared.

NIH officials reached the same conclusion. But they added in a separate report that Burden did not engage in scientific misconduct and acted properly in exposing the claims by Baldwin that could not be supported. The NIH report also expressed reservations about the fairness and objectivity of MIT's handling of Burden's complaint.

Kenneth D. Campbell, a spokesman for MIT, insists that Burden was treated fairly. "There was no bias against Burden at MIT, as asserted by the OSI [the predecessor of ORI]," he says. Burden subsequently left MIT for New York University.

Problems with the sabotage of experiments also occurred at UCSF in the laboratory of Lily J. Jan, where Baldwin worked for four years after leaving MIT. Baldwin was investigated with others by UCSF at the time, as he was one of those working in the laboratory, but the investigation did not find who was responsible.

After he left UCSF early in 1994, Baldwin returned to the United Kingdom, taking up a position in the experimental pathology division at Guy's Hospital in London. But problems arose there. Baldwin acknowledges resigning his research position at Guy's in September 1995 while he was under investigation for harassing a colleague by sending him offensive sexual material.

Guy's Hospital spokeswoman Carol Meads declines to discuss Baldwin's case, except to note that the hospital has policies for checking the references of all applicants. Baldwin says he resigned from Guy's during the investigation because "it was obvious I was not getting a fair shake". He acknowledges he sent the offensive material, but declines further comment.

At Glaxo Wellcome's Geneva Biomedical Research Institute, the director, Jonathan K. C. Knowles, says he knew that he was hiring a scientist with a troubled past when he employed Annemarie Surprenant, a neurophysiologist, in late 1993.

Officials at Oregon Health Sciences University in Portland had found in 1992 that Surprenant falsely claimed in three grant applications to the NIH that she earned a medical degree in 1976 from the University

\section{Private investigators track down fraudsters}

London. A former British police detective and a medical doctor have turned 'fraudbusters' and set up a private agency to investigate fraud and misconduct in clinical research, particularly that related to the testing of drugs.

Medico-Legal Investigations is offering to conduct investigations into possible research and other fraud in health service trusts, health authorities and the pharmaceutical industry. It is run by Frank Wells, former director of medical affairs for the Association of the British Pharmaceutical Industry, and Peter Jay, a former police detective.

Jay has since been investigating fraud and other malpractice for the solicitors to the General Medical and Dental Councils, while Wells is the author of a text- book on medical research fraud. The pair claim in their publicity brochure to be able to achieve "faster results" than more conventional procedures, to defuse "delicate situations" and to turn around "adverse press criticism".

But the prospect of latter-day Sherlock Holmeses using magnifying glasses to examine laboratory notebooks has been met with some nervousness in the medical community. David London, for example, registrar of the Royal College of Physicians of London, says that he is cautious about the idea, which has not says that he would prefer to see the agency brought under "the umbrella of an official body, rather than [being] freelance". yet been discussed at the college. He

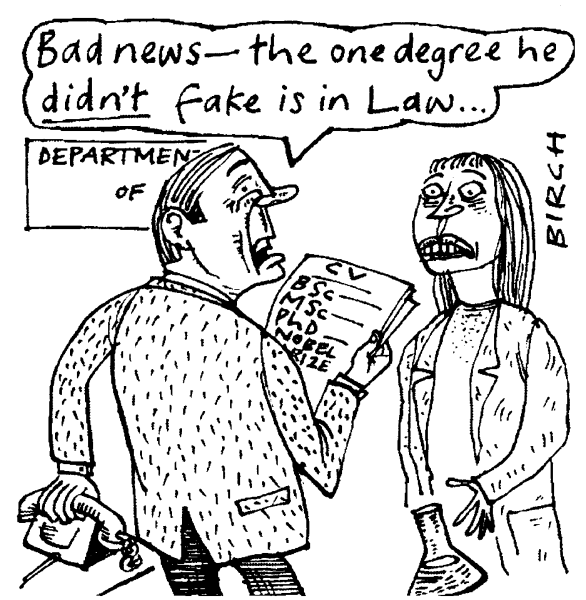

of Illinois at Chicago. There was no record of her having attended that university. She received her doctorate in physiology in 1979 from Monash University in Australia.

It was learned during the Oregon probe that Surprenant had falsely stated that she had a medical degree when she was hired for a job at MIT in 1983. The Oregon report says Surprenant was recruited to MIT by R. Alan North, a British-born neuroscientist who is now her husband.

In May 1994, Surprenant acknowledged scientific misconduct in an ORI settlement agreement, which barred her from receiving US government grants for three years. In an interview, she at first said the false listing of a medical degree on her CV was "a clerical error". Then she acknowledged that she "had made a mistake".

"I thought I had a medical degree," said Surprenant. But, she added, the difficulties in the US are irrelevant. "I signed the ORI settlement to put this away, so my research could continue. I stand behind every piece of research I have ever done."

Knowles says Surprenant and North moved as a research team to Geneva, and he has been extremely happy with their work. "My job is not to supervise the scientific establishment of the United States," Knowles says. "My job is to maintain a high standard of science at this institute." He argues the NIH acted properly and well in Surprenant's case. "Obviously, mistakes were made. I was interested in having (Surprenant) do another job. She does it well."

Whatever the circumstances surrounding individual cases, an increasing number of scientists feel that more effective procedures are needed by which scientific institutions can communicate freely - and in confidence - about the past behaviour of researchers without the risk of litigation.

"Sooner or later most large institutions have to deal with this kind of problem," says Raff. "There are powerful forces on individuals to keep this type of thing quiet," he says, arguing that it is not in the interests of research group leaders, for example, to publicize misconduct that has occurred in their own laboratory. "But it cannot go on like this. We need ways to protect institutions and scientists." 